Before treatment, psychological well-being and housework ability are altered in more than $50 \%$ of the patients. Impact on economy, food and social life occurs in less than $25 \%$ of the cases.

Life quality is mostly altered by pain (85\%), then fatigue $(75 \%)$ and handicap (58\%)

We find a correlation between the severity of RA and the importance of the impact on psychological well-being, sexual life and hobbies.

After treatment, psychological well-being improves in $53 \%$ of the patients, and social life, work, getting about and sexual life in $45 \%-32 \%$.

Items improved around $50 \%$ of the patients are in order: sleep, relation to other people, feeling excluded, social life, depression, sick leave, concentration problems, anxiety and shopping.

We find and improvement in a third of cases in house-keeping, going out, sports and libido.

$72 \%$ of the patients feel a lack of listening by their families, even under treatment Conclusions: Treatment of RA, including drugs and associated measures, reduces the frequency of negative impact on life quality.

We observe that, when DAS28 drops by $43 \%$, the frequency of RA related repercussions diminishes by $31 \%(14 \%-50 \%)$ on the chosen items. All the items are impacted by RA before treatment and stay impacted after treatment, but less frequently, except family relations. More than one patient of 2 gains correct sleep and almost half of them aren't depressed or anxious anymore. Impact on social activity and house-keeping activity are less frequently improved.

Regarding these facts, the rheumatologist has to accomplish a tight follow-up and suggest, besides drug treatment, associated measures like physiotherapy, professionnel activity and environment adaptation and rest among others.

A qualitative evaluation of the improvement will be the subject of a further study. Disclosure of Interest: None declared

DOI: 10.1136/annrheumdis-2018-eular.2274

\section{AB0321 NEGATIVE CORRELATION OF THE ABSOLUTE NUMBER OF CD4 +CD25+FOXP3+REGULATORY T CELLS TO THE LEVELS OF RHEUMATOID FACTOR IN PERIPHERAL BLOOD OF NEW ONSET PATIENTS WITH RHEUMATOID ARTHRITIS}

X. Jianfang ${ }^{1}$, C. Gao ${ }^{2}$, X. Li ${ }^{1}$, G. Liu'. ${ }^{1}$ Second Hospital of Shanxi Medical University, Taiyuan, China; ${ }^{2}$ Pathology, Brigham and Woman's Hospital, Boston, USA

Background: Rheumatoid arthritis (RA) is a progressive immune-mediated disease that can culminate in joint destruction and early mortality. High levels of serum RF are associated with a worse prognosis in RA. The role of is not fully understood. Recently, Our studies have found that the absolute number of peripheral $\mathrm{CD}^{+} \mathrm{CD}^{+} 5^{+} \mathrm{Foxp}^{+}$regulatory $\mathrm{T}\left(\mathrm{CD} 4^{+} \mathrm{Treg}\right)$ cells decreased in RA patients. Interestingly, regulatory $T$ cell epitopes (Tregitopes) in IgG have been reported as the main component of intravenous immunoglobulin therapy (IVIG) and provide one explanation for the expansion and activation of Treg cells following IVlg treatment. We hypothesise that RF joins with IgG to form large molecular complexes, which interrupts the production of Tregitopes in antigen presenting cells as a cause of reduction of $\mathrm{CD} 4^{+}$Treg cells.

Objectives: The aim of this study is to investigate whether the absolute number of $\mathrm{CD} 4^{+}$Treg cells is associated with the titers of auto-antibodies in blood of newonset diagnosed patients with RA.

Methods: A total of 57 new-onset diagnosed patients with RA were enrolled and healthy donors as control. The absolute number of peripheral $\mathrm{CD} 4^{+}$Tregs cells was detected by multicolor flow cytometry combined with an internal microsphere counting standard. 46 of new-onset cases were tested the levels of RF and antiCCP with ELISA method. IIF method was used to detect APF and AKA. Low titers group and high titers group around with the value $1: 80$. All data was analysed by SPSS 22.0.

Results: The absolute number of $\mathrm{CD}^{+}$Treg cells in peripheral blood of newonset patients with RA was significantly lower than in healthy controls [25.1 $(16.01,40.75)$ vs $33.0567(22.9,43.18), p<0.05]$. Interestingly, the reduction of peripheral $C D 4^{+}$Treg cells was negatively correlated to RF titers (correlation coefficient $-0.488, p<0.01$ ) but not to other auto-antibodies against CCP, APF and AKA. The absolute number of $\mathrm{CD} 4^{+}$Tregs in high titers RF group was lower than in low titers RF group $[20.5(14.0,40.0$ vs $34.0(29.7,44.6), p<0.05]$. There was statistically significant difference in two titers groups.
Abstract AB0321 - Table 1. Spearman correlation analysis of absolute number of CD4 ${ }^{+}$ Treg cells and autoantibodies titers in 46 new-onset RA patients

\begin{tabular}{lllll}
\hline & RF & AKA & APF & a- \\
& & & & CCP \\
\hline $\begin{array}{l}\text { CD4 } \\
+ \text { Treg }\end{array}$ & $-0.488^{* *}$ & -0.126 & -0.328 & 0.104
\end{tabular}

+ Treg

${ }^{* *} \mathrm{p}<0.01$

Abstract AB0321 - Table 2. The absolute number of CD4+Treg cells Contrast with different titers group

\begin{tabular}{lcccc}
\hline RF & $n$ & $M\left(P_{25}, P_{75}\right)$ & $Z$ & $P$ \\
\hline Low titer & 13 & 34.0 & -2.127 & 0.033 \\
group & & $(29.7,44.6)$ & & \\
High titer & 33 & 20.5 & & \\
group & & $(14.0,40.0)$ & & \\
\hline
\end{tabular}

A

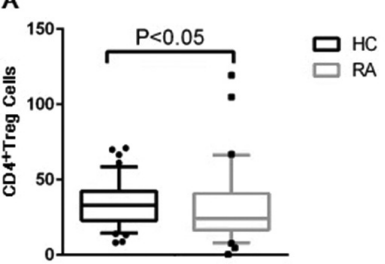

B

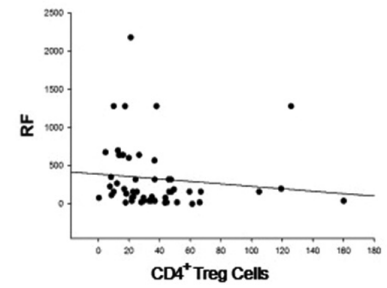

c

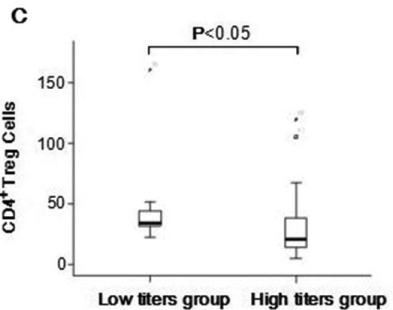

Abstract AB0321 - Figure 1. The absolute number of $\mathrm{CD}^{+}{ }^{+}$Treg cells were reduced in peripheral blood of the all enrolled new-onset RA patients $(n=57)(A)$. The reduction of peripheral $\mathrm{CD} 4^{+}$Treg cells from new-onset patients were negatively correlated with the levels of RF tested in these subjects (B). There was statistically significant difference in two titers groups of RF (C).

Conclusions: The absolute number of CD4 ${ }^{+}$Treg cells in peripheral blood of new-onset patients with RA was significantly decreased compared with that in health controls. Furthermore, the reduction of peripheral CD4 ${ }^{+}$Treg cells was negatively correlated to the titers of $\mathrm{RF}$, suggesting that $\mathrm{RF}$ contributes to the reduction of CD4 + Tregs cells. The correlation of decreased CD4 ${ }^{+}$Treg and RF may be involved in the pathogenesis of poor prognosis in RA.

\section{REFERENCE:}

[1] Cousens LP, Najafian N, Mingozzi F, Elyaman W, Mazer B, Moise L, Messitt TJ, Su Y, Sayegh M, High K, Khoury SJ, Scott DW, De Groot AS. In vitro and in vivo studies of IgG-derived Treg epitopes (Tregitopes): a promising new tool for tolerance induction and treatment of autoimmunity. J Clin Immunol 2013 Jan;33(Suppl 1):S43-9. doi:10.1007/s10875-012-9762-4 [Epub 2012 Sep 2. Review].

Disclosure of Interest: None declared DOI: 10.1136/annrheumdis-2018-eular.4959 